\title{
The multidisciplinary origin of soil geography: A review
}

\author{
Jesús Rodrigo-Comino $^{\mathrm{a}, \mathrm{b}, *}$, José María Senciales ${ }^{c}$, Artemi Cerdà ${ }^{\mathrm{d}}$, Eric C. Brevik ${ }^{\mathrm{e}}$ \\ a Instituto de Geomorfología y Suelos, Department of Geography, University of Málaga, 29071 Málaga, Spain \\ ${ }^{\mathrm{b}}$ Physical Geography, Trier University, 54286 Trier, Germany \\ ${ }^{\mathrm{c}}$ Department of Geography, University of Málaga, 29079 Málaga, Spain \\ d Soil erosion and Degradation Research Group, Department of Geography, University of Valencia, 46010 Valencia, Spain \\ e Department of Natural Sciences, Dickinson State University, Dickinson, ND, USA
}

\section{A R T I C L E I N F O}

\section{Keywords:}

Soil geography

Geography

K.D. Glinka

Soil mapping

Natural and human factors

\begin{abstract}
A B S T R A C T
Soil geography should be clearly recognized as a sub-discipline of physical geography and soil science, but at various times over the last century it was accepted as a complementary and descriptive sub-discipline of botany, agronomy and geology. In other words, there was not a clear consensus about its definition and origins. The main goal of this paper is to conduct a historical review (s. XX-XXI) of soil geography to clarify its origin, early methods, first authors and the importance of its interdisciplinary perspective within the scientific community. We found that soil geography was considerably advanced by the work of K.D. Glinka (1867-1927), one of Dokuchaev's students, who could be considered as the father of soil geography. Following the scientific line of Glinka, C.F. Marbut (1863-1935) could be considered one of the first world-reknown soil geographers. During the 1900s, this discipline continued to develop with research conducted by scientists including Kellogg, Simonson, Kubiëna, Huguet del Villar, Fitzpatrick, Duchaufour, Stremme, Zinck and entities such as USDA, FAOUNESCO and CSIRO.
\end{abstract}

\section{Introduction}

Even before the scientific study of soils, early people utilized soil knowledge. Humans have made use of soils as raw materials for cultural purposes for a long time; one prime example is the use of hematite from soil in the prehistoric pigments employed in Paleolithic wall paintings in the Roucadour Cave (France) (Ospitali et al., 2006). Neolithic human groups considered the fertility of soils and their ability to provide food resources when choosing sites for settlements; this could be considered an early example of practicing what would become soil geography (Miller and Schaetzl, 2014). Another example is the use of soil spatial patterns to select cropping sites by 3000-2000 BCE (Krupenikov, 1992). Soil knowledge and its relationship with human practices developed in parallel with agriculture (Desruelles et al., 2016). At the beginning, these strong relationships were relevant in three specific areas: the Fertile Crescent (Western Asia, the Nile Valley and Nile Delta), Mexico, and Hindustan and East China (Porta et al., 2014). In fact, the Chinese had soil classification systems to assist in agricultural management as far back as 4000 BCE (Gong et al., 2003).

In the Western World, one of the most interesting links is related to Plato, philosopher in Classical Greece and the founder of the Academy in Athens. Plato remarked on the importance of soil loss and its distribution after observing some landslides near the expanding urban limits of the city of Athens (Fitzpatrick, 1980).

During the next few centuries, two groups started to design better strategies to qualitatively evaluate soil properties and fertility: religious congregations and the Muslim civilization (Rodrigo-Comino and Senciales González, 2013). The monks insisted upon the development of tillage and ploughing practices that removed soil horizons using animal labor during different seasons, and claimed that soil conservation techniques were important due to religious reasons (Hope and Jones, 2014). In the Arabian civilization, the Muslim worked on high quality irrigation systems driven by gravity to maintain moist, welldrained soils (Harrower, 2010). In fact, many soil scientists agree that one of the milestones in the rise of agronomy took place with the developed of the Arab gardens, and the work of Columella (4 BCE - c. $70 \mathrm{CE}$ ) is considered the beginning of soil science (Olson, 1943). In the southwestern part of the modern-day USA, Native American tribes chose their agricultural fields based on soils and landscapes to maximize water retention and runoff collection (Brevik et al., 2017).

Despite all these precursors, soil geography only became a scientific discipline following the ground-breaking research carried out by the Russian school of landscape studies during the 19th and 20th centuries (Antipov and Semenov, 2006; Shaw and Oldfield, 2007). Soil

\footnotetext{
* Corresponding author.

E-mail address: rodrigo-comino@uma.es (J. Rodrigo-Comino).
} 
geography is now recognized as a scientific discipline and soil geographers as practicing a specific branch of science (Rodrigo-Comino and Senciales González, 2013). As a scientific discipline, soil geography should be clearly recognized as a sub-discipline of both physical and human geography and soil science, but at various times over the last century it has been accepted as a complementary and descriptive subdiscipline of geology, agronomy and even botany. In other words, there was not a clear consensus about its definition and origins.

Several scientists and international organizations have performed research related to the establishment of pedological taxonomies that include a soil geographical point of view such as USDA (United States Department of Agriculture), FAO (Food and Agriculture Foundation) and CSIRO (Commonwealth Scientific and Industrial Research Organization). In addition, there is a geographic component to some of the most influential soil models used by modern scientists, such as those of Jenny and Runge (Brevik et al., 2016a). In many instances it is difficult to distinguish a clear line that separates soil science from soil geography.

The main goal of this paper is to carry out a historical review of soil geography to clarify its origin, early methods, first authors and the importance of its interdisciplinary perspective within the scientific community. The main reasons to make this historical review are: i) there is a lack of information about a correct definition of the soil geography discipline; ii) to the best of our knowledge, there are no studies focused on demonstrating the importance of soil geography as an integrated discipline within the soil sciences, geography and land management; iii) to help soil geographers with a consistent state of the art review to facilitate their future works; iv) and to clarify the origin and evolution of the discipline and avoid misunderstandings and lack of information; and, v) encourage other colleagues to contribute with research about the origin and evolution of soil science at national, regional, and even local approaches.

To achieve these goals, a short review of where soil geography acquired its methods will be given. Then early soil geographers will be discussed. A definition of soil geography and procedures within the context of geography, soil science, and territory will be presented. And a chronology of the main events, investigations and early researchers who have contributed to the soil geographical point of view will be provided.

\section{The birth of soil geography and the first soil geographers}

\subsection{Agroecology and soil science as the scientific basis of soil geography}

Some scientific disciplines such as chemistry and physics can be defined and their origins described without mentioning other fields such as geology, astronomy or botany. However, to enunciate a definition of soil geography and to find its roots, it is mandatory to highlight its clear dependency on agroecology and geology (McCracken and Helms, 1994; Tricart, 1962).

During the 1800 s, the basis of soil science was established after specific investigations related to biochemical soil properties such as organic matter, color, mineralogy and biodiversity by scientists including J.G. Wallerius, Rieule, T. de Saussure, J. von Liebig and J.B. Boussingault. Based on these investigations the German agronomist Philipp Carl Sprengel published the first book strictly about soil science ("Die Bodenkunde") in 1837, which could make him the father of European soil science (Huguet del Villar, 1929). Another relevant event also occurred in Germany. The agroecologist Emil Ramman (1851-1926; he became Prof. of Soil Science in 1895 and 1900 moved as such to Munich), following on work done by Albrecht Thaer, von Richtofen, Albert Orth and Friedrich Fallou (Tandarich et al., 2002), started to describe soil weathering processes (Ramman, 1893), classified soils into two general groups (residual and alluvial), and developed the first scientific diagrams of soil profiles (Hartemink, 2009). In the USA, Eugene Woldemar Hilgard (Fig. 1a), considered a co-father of modern soil science by some researchers (Brevik et al., 2016b; Jenny, 1961), began his innovative studies into soil as an independent body and the influence of climatic parameters on pedogenesis (Hilgard, 1860, 1882, 1907).

The last important event in laying the early groundwork for soil geography occurred between 1877 and 1878, when the geologist and geographer Vasily Vasili'evich Dokuchaev (Fig. 1b) conducted his investigations of the soils of Ukraine for the Russian Government as a solution was sought for decreased agricultural production due to extremely dry periods (Bazykina, 2006; Fitzpatrick, 1980; Sánchez-Puig, 1995). Dokuchaev has been credited with developing the first scientific classification of soils, which included the Chernozem (Fig. 1c), methods for soil mapping, and establishing the foundation for the study of both soil genesis and soil geography (Buol et al., 2011). It is ironic that Dokuchaev himself refused to be associated with the field of geography and did not feel that soil science was linked to geography (Shaw and Oldfield, 2007).

Dokuchaev's findings were contradictory to those of his predecessor, Professor Mikhaíl Vasilievich Lomonósov, who wrote in his book About the Layers of the Earth and other Works on Geology in 1757 that soil should be considered a static entity and a simple part of the geological substratum (Lomonosov et al., 2012). Dokuchaev collaborated with other research groups from different disciplines such as geobotany, hydrogeology and geomorphology (Moon, 2005). During these collaborations with scientists such as V. Vernadskii and M.S. Giliarov (Dobrovol'skii, 2011), Dokuchaev and his students developed important ideas that shaped the future basis of soil geography: i) the soil as an interface between the atmosphere, lithosphere and biosphere; and ii) the application of different bio- and geoindicators to classify soil such as color, animals or insects, geomorphological features in the landscape and agricultural impacts (Oldfield and Shaw, 2013; Striganova, 2013). These ideas related to the natural and harmonious agreement between humans and the environment, indispensable to understand the development of the territory or land (Kiryushin, 2006). However, these ideas did not become widespread due to the difficulty of translating the Russian language and the controversial debates in Central Europe between geography and geology. The traditional European geologists assessed only some specific soil properties or viewed soil as a simple part of the geological substratum without inherent differences between them (Fitzpatrick, 1980; Tricart, 1962).

Despite the problems and challenges, Dokuchaev's students and other followers were eventually able to promote his ideas to scientists around the world (Dobrovol'skii, 2011; Kiryushin, 2006; Prokhorov, 1982; Semyonov, 1998). Those who promoted Dokuchaev's ideas included P. Semiónov (in Germany with the geographers Alexander von Humboldt and Karl Ritter), N.M. Sibirtsev (the first full professor of soil science), A.N. Sabatin (founder of the Academy of Soil Science in Moscow) and K.D. Glinka (influenced C.F. Marbut, who successfully introduced Russian ideas to the USA, and worked with the German soil scientist Hermann Stremme, a student of Albert Orth). In the USA G.N. Coffey was one of the first to introduce Russian ideas on soil science, but unlike Marbut was not successful in his attempts (Brevik, 1999).

\subsection{K.D. Glinka and the birth of soil geography as a scientific discipline}

Soil geography was considerably advanced by the work of Konstantin Dmitrievich Glinka (1867-1927), one of Dokuchaev's students. Despite his apparent disconnect with geography at the beginning of his career because of his taxonomic point of view (Shaw and Oldfield, 2007, 2015), Glinka generated novel ideas about pedogenesis and soil cartography following the ideas of the Geobotanical School of Kazan that was developed by S.N. Korzhinskii and A.Y. Gordyagin (Dobrovol'skii, 2006; Muggler et al., 2012). One major contribution, which is highly used nowadays, was the recognition of soil horizons as a key component to classify soils using the A, B and C nomenclature (Tandarich et al., 2002; Wilde, 1949; Yaalon and Berkowicz, 1997). 


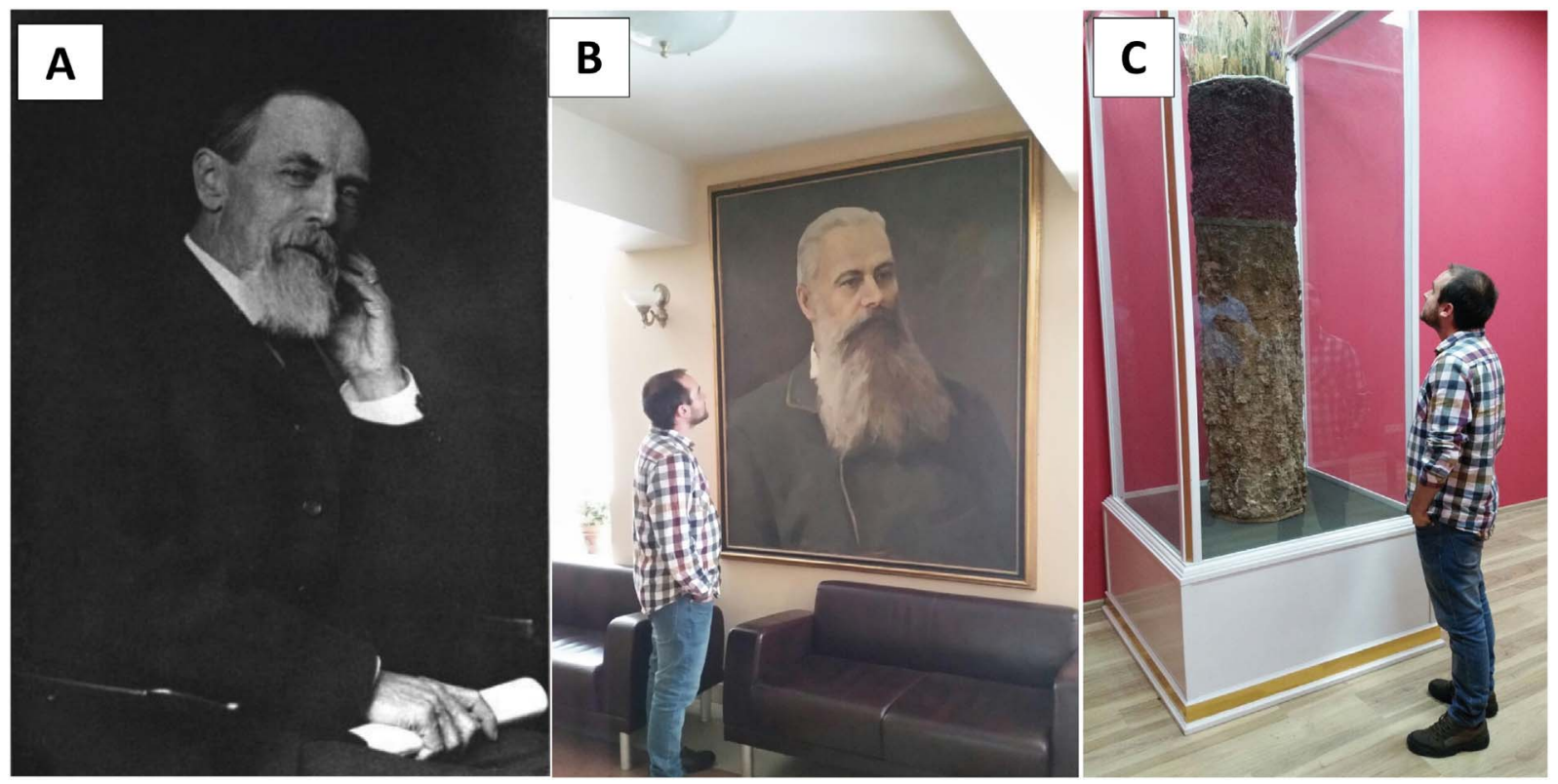

Fig. 1. E.W. Hilgard (A); V.V. Dokuchaev (B); Chernozem's monolith in V.V. Dokuchaev Soil Science Institute Moscow, Russia (C).

This system was improved and published in English from the original German (Glinka and Marbut, 1927). From 1906 to 1910, Glinka coordinated different expeditions to perform qualitative soil assessments in Kazakhstan. From this data base, Glinka detected some important factors that conditioned pedogenesis: i) local climate characteristics highlighting the effects of variation in humidity, ii) vegetation, and iii) parent material. These factors were used to create the first complete soil classification, characterized by six groups and 23 sub-types (Glinka, 1914; Glinka and Marbut, 1927). From a soil geography perspective, the most relevant of this research was that Glinka emphasized the environment-human relationship over the territory where pedogenesis was occurring (Rodrigo-Comino and Senciales González, 2013). Glinka was also the founder of the Dokuchaev Soil Committee and the Soil Institute (Shaw and Oldfield, 2007).

Following the scientific line of Glinka, C.F. Marbut (1863-1935) could be considered one of the first world-renown soil geographers (Fig. 2a and b). He was a brilliant student of the father of American geomorphology, W.M. Davis (Sack, 2002). Through Marbut, Davis' concepts of landscape evolution were applied to pedogenesis (Brevik et al., 2016b; Lankford et al., 1985b). Marbut's published and nonpublished works clearly highlighted two concrete interests (Lankford et al., 1985a): i) to close the separation between soil geography, geomorphology, geobotany and biogeography; and, ii) to synthetize the knowledge of soils within the global environmental sciences. Decades later, these two concepts were also applied in the German school of geobotany and Russian landscape studies or ecogeography, although their studies were highly focused on abiotic elements (Isachenko, 2003; Melnyk, 2008; Tricart and Kilian, 1982).

Therefore, we can observe that from a multidisciplinary point of view soil geography had found its scientific roots. The main goals of the next generation of soil geographers would be to: i) classify soils, ii) delineate them over known areas of territory and; iii) achieve sustainable land management.

\subsection{Soil geography during the 20th and 21st centuries}

In the early 1900s, C.F. Marbut led the first complete study of the soils at a country-wide scale, which was based on the national scale soil survey established in the USA by Milton Whitney in 1899 (Brevik et al., 2016b). Marbut took over from Whitney when he retired and designed a hierarchical classification with multiple categories and a complete list of elements to identify the described soil profiles (Strahler and Strahler, 2002) (Fig. 3). Marbut's work formed the basis for the first USDA Soil Survey Manual (Kellogg, 1937) published since 1914 (Simonson, 1986). In 1951, C.E. Kellogg led the creation of the 1951 and 1975 editions of the Soil Survey Manual, which was applied worldwide by soil survey organizations. Moreover, R.W. Simonson and G.D. Smith (Fig. 4b) worked on the expansion of soil survey interpretations for agricultural and non-cultivated areas as well as renewing soil geomorphology, soil science and soil geography research (Helms, 2002, 2005) and the USDA provided major support for studies in soil geomorphology beginning in 1953 (Brevik et al., 2016a). Another important American contribution from this time was that of Hans Jenny (Fig. 4), who cast the five soilforming factors into a state factor equation. One of the main goals of Jenny's model was to explain the geographic distribution of soils (Holliday, 2006).

In Germany, W.L. Kubiëna (Kubiëna, 1952, 1953) was one of the most important soil scientists and promoted the importance of the evolutionary process of soils interpreted through their pedo-morphological characteristics (Fig. 5a). This research line was considered useful for the elaboration of soil mapping at the regional scale (Tricart, 1962). During the 21st century, soil geography (in German Bodengeographie) is commonly established in many faculties of geosciences, usually as a subdiscipline of physical geography (Eitel and Faust, 2013; Gebhardt et al., 2012). The German soil geography school was also highlighted by the creation of the first international soil map of Europe (Stremme, 1928, 1937), published on 12 sheets that totaled $4.8 \mathrm{~m}^{2}$ and had input from 36 colleagues (Stemme, 1997) led by the geologist and minimalist Herrmann Stemmer (1879-1961).

In Spain, E. Huguet del Villar (Fig. 5b) was the president of the International Association of Mediterranean Soil Sciences and introduced the term "edafología" in Spanish (edapho -instead of pedo$=$ soil from the old Greek). Huguet del Villar led and published several research projects related to the soils of Europe and the Iberian Peninsula (Albareda Herrera, 1940) and even influenced the Chinese soil classification system developed by Drs. Hou and Wong (Huguet del Villar, 1929). In his studies, del Villar stressed the importance of the term "geopedology" and associated it with several soil geographic research areas such as the Hindustan Peninsula or France, although the term evolved to "edafogeografía" (edaphogeography). In practice, only two general manuals contain the word "edafogeografía" in their titles (Ferreras and Fidalgo, 1991; Rodrigo-Comino, 2017). 


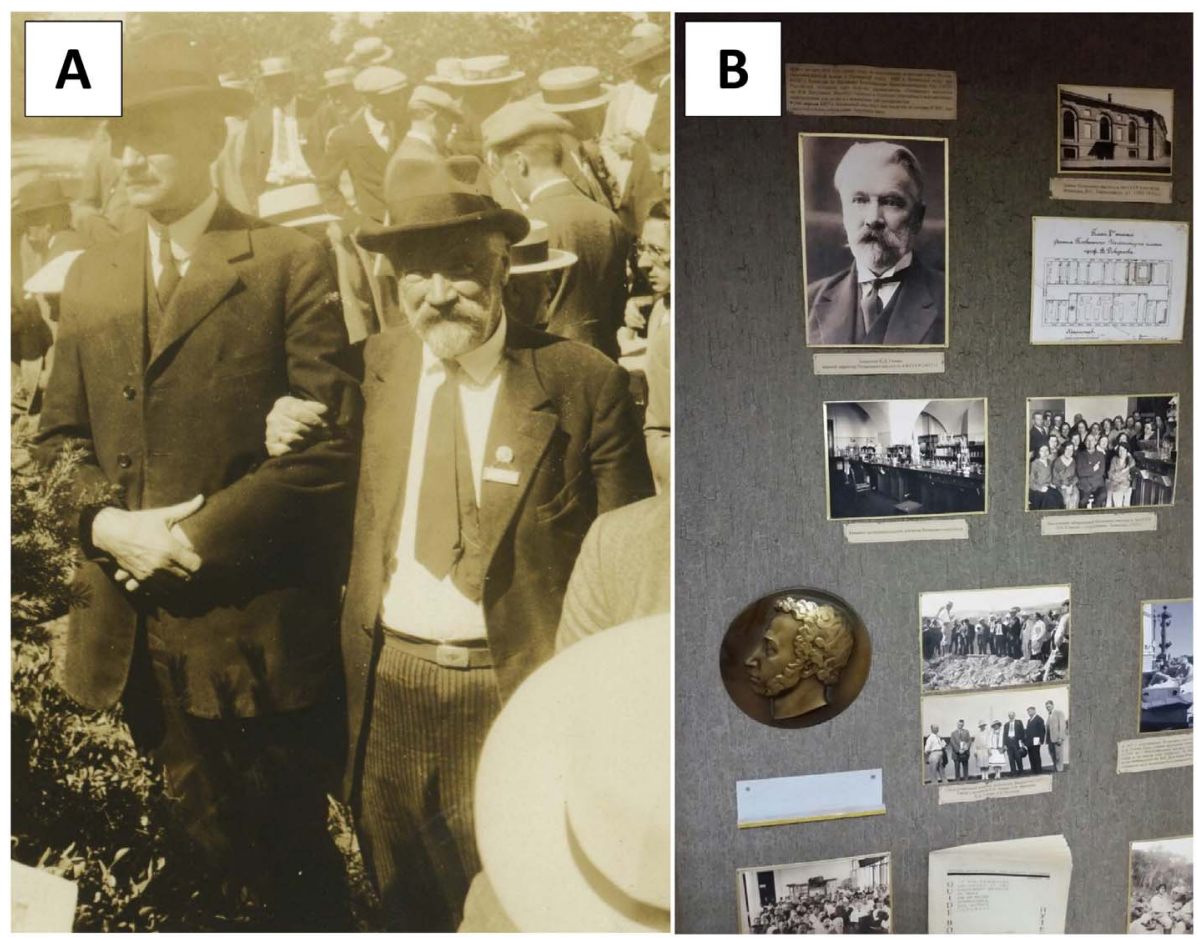

Fig. 2. K.D. Glinka and C.F. Marbut (A), K.D. Glinka and soil science community pictures (V.V. Dokuchaev Soil Science Institute Moscow, Russia).
After the Second World War, CSIRO implemented the use of aerial photography in its first soil classification in Australia (Jacquier et al., 2002; Northcote and Northcote, 1979). This tool became very important in soil mapping (Fitzpatrick, 1980; Miller and Schaetzl, 2014) following its development for soil survey purposes in the USA in the 1920s and 1930s (Pereira et al., 2017). Together with USDA Soil Taxonomy, the World Reference Base (WRB) developed by FAO-UNESCO in collaboration with the IUSS (International Union of Soil Sciences) have focused on classifying soils to promote agricultural and other forms of development (IUSS Working Group WRB, 2006). Most specifically, WRB establishes all its classifications within the scope of soil geography (IUSS Working Group WRB, 2006, 2014).

In France, P. Duchaufour (1912-2000; Centre biologique e pedologique de CNRS and president of the "Centre national de la recherche scientifique") was the most important individual related to soil science and soil geography between 1960 and 1990 (Fig. 5c). His research was related to genetic soil classification and land use planning (Duchaufour, 1956, 1970, 1997, 1998). In Scotland, Prof. Ewart A. FitzPatrick (Fig.5d) also worked with genetic classifications trying to find the most accurate explanation for soil distribution over the landscape and using a coordinate system with specific typologies (Fitzpatrick, 1980).

In The Netherlands, other remarkable soil geographers who were highly influenced by geomorphology (van Zuidam and van ZuidamCancelado, 1979; Verstappen et al., 1991) were in the ITC research group (Geo-Information Science and Earth Observation of the University of Twente). Specifically, A. Zinck worked on soil geographic databases, soil geomorphology and geopedology (Zinck, 2012; Zinck and Valenzuela, 1990a) without forgetting about other factors such as vegetation and climate (Ibáñez et al., 2013). Another remarkable place where soil geography plays an important role is in the ISRIC (International Soil Reference and Information Centre) in Wageningen. In this research center, the academics focus on serving the international community "as custodian of global soil information", providing information about the understanding of soils in major global issues.

\section{The main procedures of actual and applied soil geography}

Soil geography shares sources and methods with agronomy, soil sciences, ecology, geology and physical geography (geomorphology and biogeography). However, it is possible to establish some fundamental principles and procedures that distinguish it from other disciplines as shown in Fig. 6 . These distinguishing principles are not closed, they are shared with other closely related fields, and soil geography is not only about cartography (Philipponneau, 1999), but rather follows the geographic method (Claval, 2001; Ortega Valcárcel, 2000; Schaefer, 1953).

In utilizing the geographic method, it is first necessary to delineate the study area (pedogeomorphic units) taking into account the different scales where all the possible human and environmental factors may intervene (Conacher and Dalrymple, 1977; Young and Goldsmith, 1977). Second, the identification and classification of soil types is mandatory by following criteria relevant to the research questions such as aptitudes, soil properties or potentialities (Riquier et al., 1970). Photointerpretation, field work, soil analyses, GIS data bases, and unmanned aerial vehicles (UAV) are some of the most important tools applied in the process of soil unit identification (Behrens et al., 2010; Brevik et al., 2016c; Bui et al., 2017; Grunewald, 2009; Le Bissonnais et al., 2002; Taylor et al., 2009). Third, a general assessment of the main environmental (geomorphological features such as falls, rills, gullies, flooded areas, etc.; types of lithology, biogeographical description such as types of vegetation and animals, distribution of main species, etc.; climate conditions such as temperature or rainfall distribution; frost risks, etc.) and human characteristics (land uses such as types of crops, evolution of land managements, etc.; demography such as amount of inhabitants, population density, etc.) must be performed in order to know the conditions under which pedogenesis was developed (Rodrigo-Comino and Senciales González, 2013). Subsequently, soil mapping is the main tool that should be used to allow the representation and observation of geographic phenomena within soil geography (Miller and Schaetzl, 2014). It may be mandatory to rethink/ review the elaborated soil cartography in order to carry out a meaningful interpretation at diverse scales without forgetting any major factor that has influenced pedogenesis and current land management.

Miller and Schaetzl (2014) and Brevik et al. (2016c) emphasized that the introduction of GPS and GIS revolutionized soil geography. These tools provide more efficient and rapid ways to obtain base maps for soil mapping such as land-surface derivatives (Florinsky et al., 

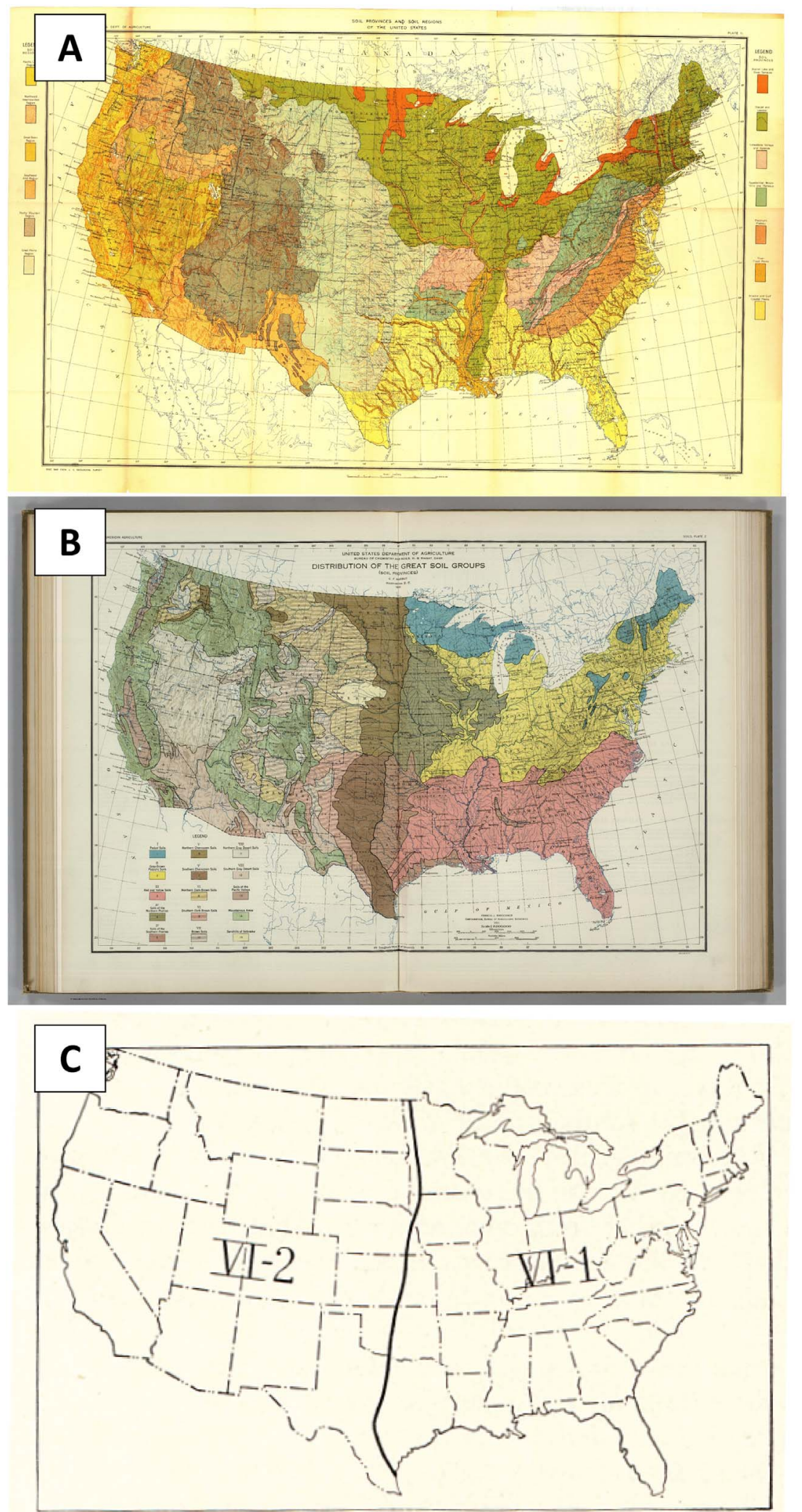

Fig. 3. Maps showing Marbut's evolving ideas regarding soil classification and distribution. Panel a - Map from Marbut et al. (1913), with soil subdivisions based on geology and physiography. Panel b Map from Marbut (1935), which is based on soil properties and incorporates Russian ideas. Panel c - Another map from Marbut (1935), which shows the USA divided between soils that contain free calcium carbonate in their profile (Pedocals, VI-2) and soils that do not have free calcium carbonate in their profile (Pedalfers, VI-1).
2002). However, they also remarked that other new tools used by soil geographers include advanced spatial statistical techniques, improved models, increasingly powerful computers, and remote and proximal sensing technologies, which are able to add new insights with additional information related to the environmental properties and their interactions with the electromagnetic spectrum (Eltner et al., 2013; Mulder et al., 2011). 


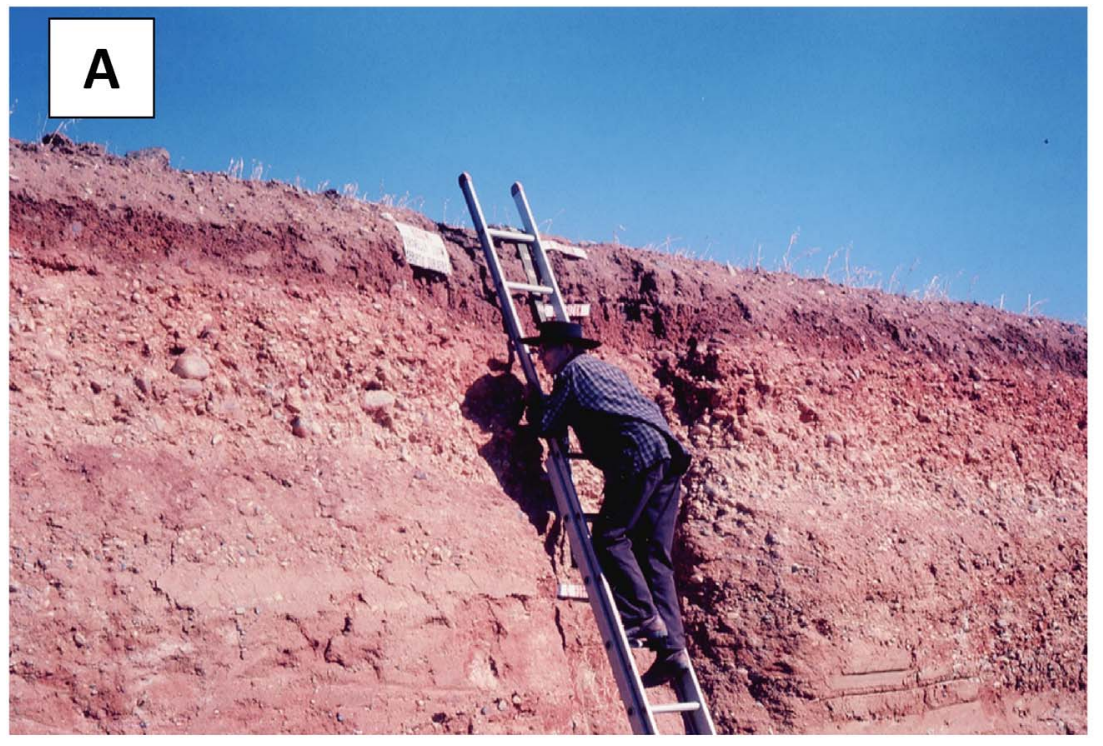

Fig. 4. Panel a - Hans Jenny inspecting a soil profile. Panel $b$ - from left to right, Roy W. Simonson, Charles E. Kellogg, I.P. Gerasimov, and Guy D. Smith. Fig. 5. W. Kubiëna (A), Huguet del Villar (B), E.A. FitzPatrick (C) and P. Duchaufour (D).

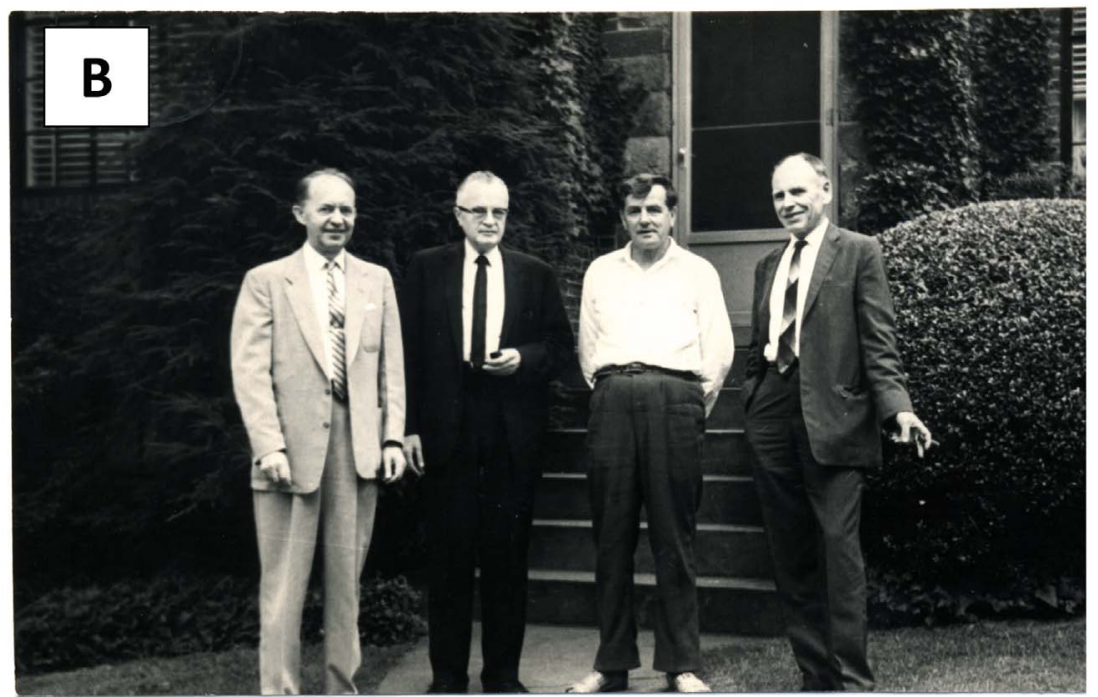

4. Investigations in soil geography: Application to land management

Soil geography has produced an abundance of applied works related to geomorphologic methods and several surface processes such as weathering, desertification, sediment and water losses or morphological changes on hillslopes (Trudgill, 1983). The first main tool that joins both applied disciplines is geomorphological mapping or soil
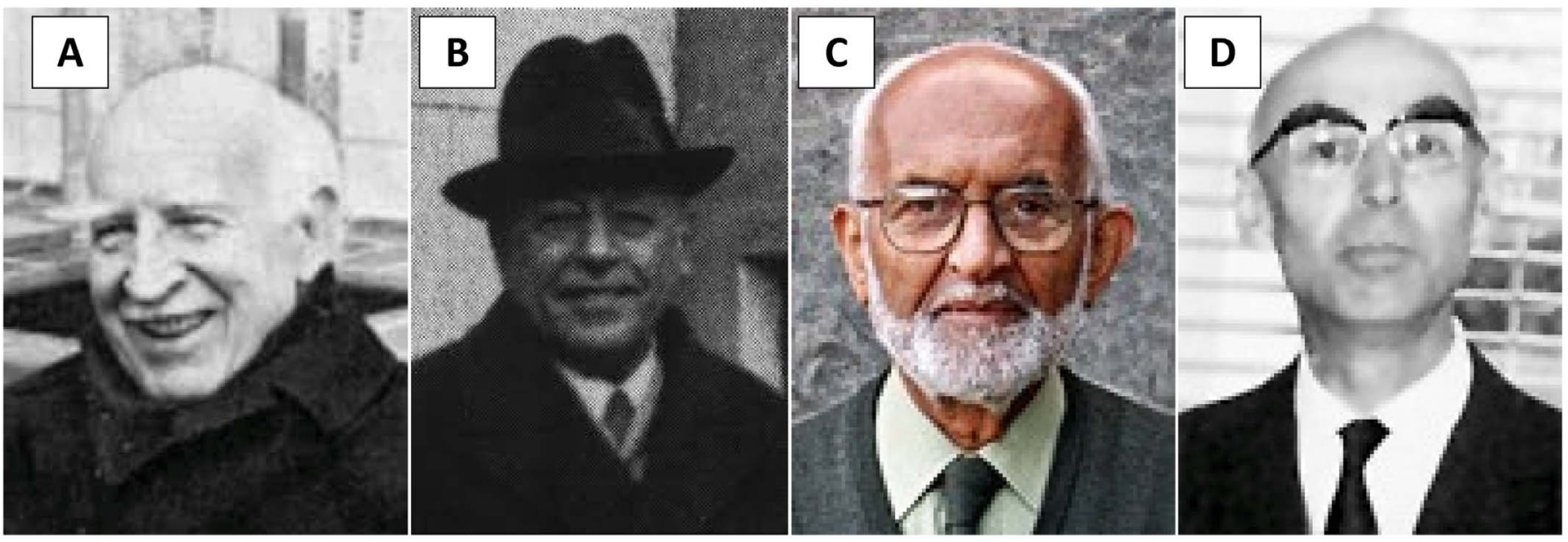

Fig. 5. From left to right: W.L. Kubiëna, E. Huguet del Villar, P. Duchaufour, Ewart A. FitzPatrick. 


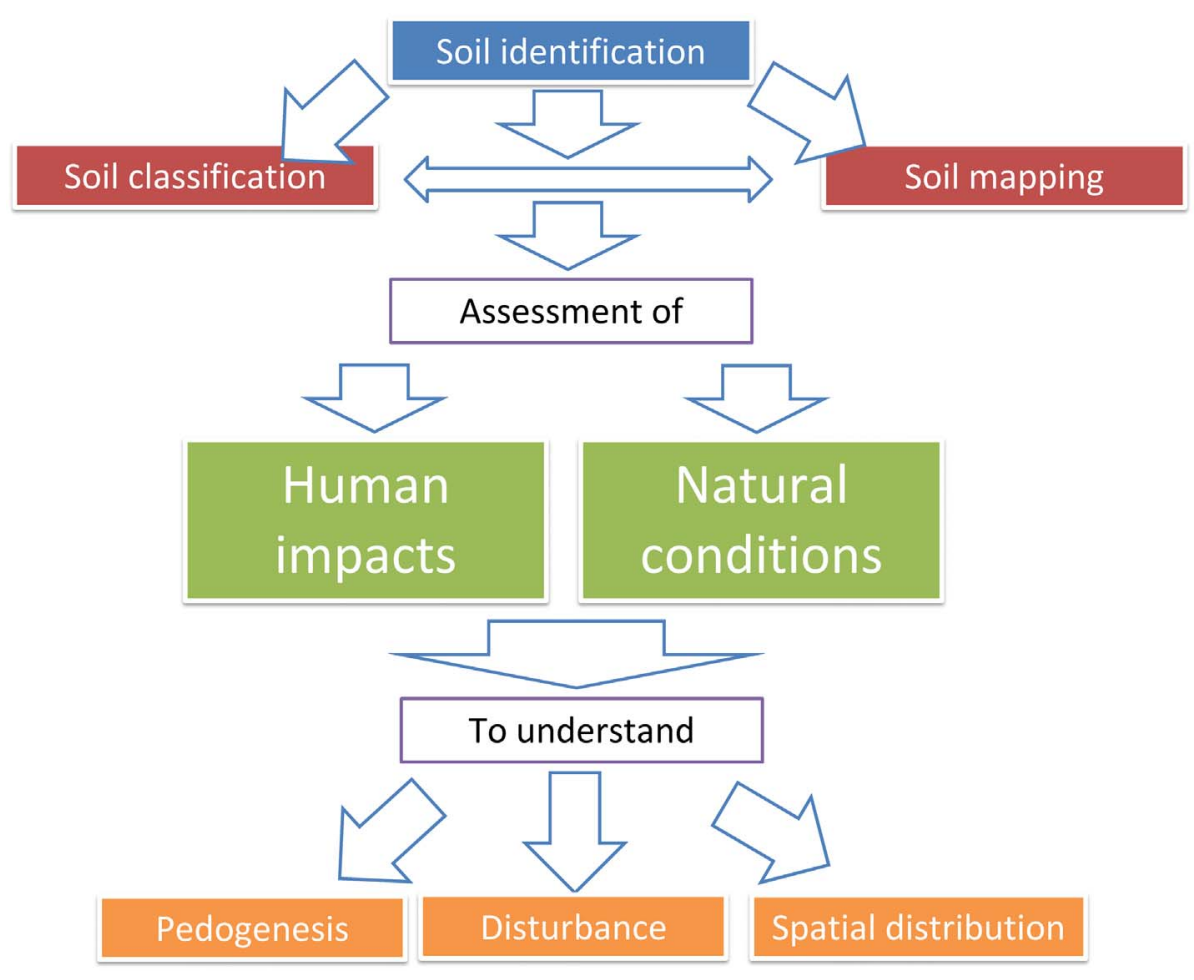

Fig. 6. The fundamental principles and procedures that distinguish soil geography as an independent field of study.

\section{il classification}

\section{Soil identification}

Assessment of

Disturbance

Table 1

Chronology of the highlights related to soil geography development.

\begin{tabular}{|c|c|c|}
\hline Chronology & Socities and authors & Contributions \\
\hline $\begin{array}{l}\text { Antecedents: From } 3.500 \text { a. } \\
\text { Chr. n. to s. XVII }\end{array}$ & $\begin{array}{l}\text { Fertile Crescent (Western Asia, the Nile Valley and } \\
\text { Nile Delta), Mexico and, Hindustan and East China }\end{array}$ & First activities related to soils and agricultural practices \\
\hline & Religious congregation and Arabian civilization & Tillage and ploughing with animals, irrigation by gravity and soil conservation \\
\hline s. XVIII-XIX & $\begin{array}{l}\text { J.G. Wallerius, Rieule, T. de Saussure, J. von Liebig } \\
\text { and J.B. Boussingault }\end{array}$ & Biochemical soil properties such as organic matter, color, mineralogy and biodiversity \\
\hline 1837 & Philipp Carl Sprengel & First book strictly about soil science ("Die Bodenkunde") \\
\hline 1893 & Emil Ramman & $\begin{array}{l}\text { Classified soils into two general groups (residual and alluvial). } \\
\text { Developed the first scientific diagrams of soil profiles. }\end{array}$ \\
\hline 1860-1907 & Eugene Woldemar Hilgard & Soil as an independent body and the influence of climatic parameters on pedogenesis \\
\hline $1877-1878$ & Vasily Vasili'evich Dokuchaev & $\begin{array}{l}\text { Developing the first scientific classification of soils such as Chernozem soil profile } \\
\text { (Fig. 1c), methods for soil mapping, and establishing the foundation for the study of } \\
\text { both soil genesis and soil geography }\end{array}$ \\
\hline 1906-1910 & K.D. Glinka & Detected important factors that conditioned pedogenesis. \\
\hline $1926-1927$ & K.D. Glinka and C.F. Marbut & $\begin{array}{l}\text { Create the first complete soil classification, characterized by six groups and } 23 \text { sub- } \\
\text { types. }\end{array}$ \\
\hline 1929 & E. Huguet del Villar & $\begin{array}{l}\text { President of the International Association of Mediterranean Soil Sciences and } \\
\text { introduced the term "edafología" in Spanish }\end{array}$ \\
\hline 1937-1938 & Herrmann Stremme & First international soil map of Europe \\
\hline $\begin{array}{l}1950 \text { (After the Second World } \\
\text { War) }\end{array}$ & CISRO & It implemented the use of aerial photography in its first soil classification in Australia \\
\hline 1956-1998 & P. Duchaufour & Genetic soil classification and land use planning \\
\hline 1951-1975 & C.E. Kellogg, R.W. Simonson and G.D. Smith & USDA Soil Survey Manuals \\
\hline 1952 and 1953 & W.L. Kubiëna & $\begin{array}{l}\text { Evolutionary process of soils interpreted through their pedo-morphological } \\
\text { characteristics }\end{array}$ \\
\hline 1961 & Hans Jenny & $\begin{array}{l}\text { Five soil-forming factors into a state factor equation to explain the geographic } \\
\text { distribution of soils }\end{array}$ \\
\hline 1979-2012 & $\begin{array}{l}\text { Van Zuidam, van Zuidam-Cancelado, Verstappen and } \\
\text { A. Zinck }\end{array}$ & Soil geographic databases, soil geomorphology and geopedology \\
\hline 1980 & Ewart A. FitzPatrick & $\begin{array}{l}\text { Genetic classifications trying to find the most accurate explanation of soil distribution } \\
\text { over the landscape and using a coordinate system with specific typologies }\end{array}$ \\
\hline
\end{tabular}

landform relationships. Gaucher $(1968,1981)$ elaborated the morphopedological mapping method where each part of the terrain represented a geomorphological unit that was associated with a specific soil type or groups of soils. The recognition of soil-landform relationships goes back to the 1930s with Milne's development of the catena concept (Gessler et al., 2000), and this type of mapping has been used in the USA since at least the 1930s, beginning with soil erosion mapping and proceeding on to soil survey; most of the legacy soil maps available in the USA today were created using soil-landform relationships (Brevik et al., 2016b). Conversely, mapped soils have also been used to provide geomorphological information (Brevik and Miller, 2015). Soil-landform relationships have been useful for tropical soil inventories within the framework of land evaluation studies beginning in the 1970s, and several authors have studied and improved the method as a part of soil survey 
(Bétard and Bourgeon, 2009; Gessler et al., 2000). Conacher and Dalrymple (1977) proposed the pedogeomorphic model, which assesses pedogenetic processes based on the morphological features of the surface. These types of units were called land surface catena. Several authors have worked on improving the methodological procedure related to the delineation of diagnostic units by overlapping lithofacies, topography, morphology, slope inclination, landscape units or vegetation cover in geographic information systems (GIS) and with remote sensing techniques (Mulder et al., 2011; Rodrigo-Comino et al., 2016; Rukhovich et al., 2011; Zinck, 2012; Zinck and Valenzuela, 1990b).

Soil geography has demonstrated a high affinity with biogeography. The main coincident methods and goals are highly related to nutrients, microorganisms, and vegetation and animal distributions. In this way, the inventories and surveys of biogeographers have frequently been used as tools in soil geography (Ibáñez et al., 2013; Tugel et al., 2006). Such applied research may be situated at the intersection between geography, biology, ecology and geobotany (Ferreras and Fidalgo, 1991; Pears, 1985; Taylor, 1984).

Dent and Young (1981) observed that land management experts would also need works that focused on the spatial distribution of soils. Modern digital soil mapping techniques include this in their output (Minasny and McBratney, 2016). In this way, soil geographers should be able to manage situations related to assessments of environmental impacts, military use, and land use planning, among others. Major advances in soil geography are highlighted in Table 1.

\section{Future horizons}

Land degradation issues increasingly need the support of a geographical approach related to the soil system (Butzer, 2005), as spatial variability is a major key to understanding system resilience and planning the appropriate application of restoration and rehabilitation strategies (Cerdà et al., 2017; Rodrigo-Comino et al., 2017a; Chen et al., 2007; Jie et al., 2002;). The need for mapping should be extended to other disciplines in ways that will help demonstrate the importance of soil geography as an applied discipline, such as Abrahams (2006) and Tabor et al. (2011) have shown related to human disease distribution and medical cartography. Another example is the interaction between biota and soils, where the role of soil geography is relevant (Ibáñez et al., 2016; Yin et al., 2010). As with any scientific field, soil geography is in a constant state of change and update, and the coming decades will see many technological advances. Human societies and their needs will change, and the environmental perception of the world will be altered just as it was over the last few decades (Bridges, 1981) and centuries (Williams, 1994). Soil geographers must be ready and willing to adjust with these changing needs, expectations, and capabilities. As one example of this, work on urban soils, which emphasize the soil-human relationship, has become increasingly important at the end of the 20th and beginning of the 21st centuries (Pickett et al., 2008; Howard and Olszewska, 2011; Howard and Shuster, 2015). Other examples include applied research devoted to solve problems such as accelerated soil erosion (Rodrigo-Comino et al., 2017b), pollution (Trujillo-González et al., 2017; Villacís et al., 2016), or soil degradation (Pereira et al., 2015, 2017; Vaezi et al., 2017). Applied soil geography brings new ideas such as ecosystem services (Galati et al., 2016; Parras-Alcántara et al., 2016), interaction with other disciplines such as agronomy (Sharma et al., 2017), hydrology (Narany et al., 2017), geomorphology (Yousefi et al., 2017) or risk assessment (Yousefi et al., 2017), and this modern soil geography seeks applied nature-base solutions (Keesstra et al., 2018) grounded in the holistic view of the soil system developed by soil geographers. This view is also present in policies developed in the 21st century such as the United Nations Sustainable Development Goals, in which soil is a key actor (Keesstra et al., 2016).

\section{Conclusions}

After carrying out a historical review of soil geography, we can consider it as a scientific discipline that is clearly recognized as a subdiscipline of geography and soil science. Despite not having a clear consensus about its definition and origins, a number of studies over the last century or more have confirmed its development and relevance. The main conclusions obtained from this historical review were: i) K.D. Glinka can be considered the father of soil geography; ii) C.F. Marbut was one of the first soil geographers known world-wide; iii) identification, soil classification, assessment of the human and natural factors that impact pedogenesis and soil distribution, and soil mapping are the main foci of soil geography; iv) soil geographers are able to carry out an important role in society by working on several issues related to the human and natural environments where soils play a determinant factor. Thus, we can define soil geography as the discipline that studies the causes of the distribution of soils and their relationship with humans.

\section{Acknowledgements}

The first author, J. Rodrigo-Comino thanks the Ministerio de Educación, Cultura y Deporte de España for the scholarship grant award (FPU15/01499). We also thank Alicia Fernández and Pasqual Ribot for the time, effort and field work during the research in Moscow.

\section{References}

Abrahams, P.W., 2006. Soil, geography and human disease: a critical review of the importance of medical cartography. Prog. Phys. Geogr. 30, 490-512. http://dx.doi.org/ 10.1191/0309133306pp493ra.

Albareda Herrera, J.M., 1940. El suelo. Biosca, Madrid, Spain.

Antipov, A.N., Semenov, Y.M., 2006. The Russian school of landscape planning. In: Vogtmann, H., Dobretsov, N. (Eds.), Environmental Security and Sustainable Land Use - with Special Reference to Central Asia. Kluwer Academic Publishers, Dordrecht, pp. 309-319. http://dx.doi.org/10.1007/1-4020-4493-3_21.

Bazykina, G.S., 2006. In memory of a classic of Dokuchaev's Pedology Aleksei Andreevich rode (1896-1979). Eurasian Soil Sci. 39, 1255-1256. http://dx.doi.org/10.1134/ S1064229306110147.

Behrens, T., Zhu, A.-X., Schmidt, K., Scholten, T., 2010. Multi-scale digital terrain analysis and feature selection for digital soil mapping. Geoderma 155, 175-185. http://dx. doi.org/10.1016/j.geoderma.2009.07.010.

Bétard, F., Bourgeon, G., 2009. Cartographie morphopédologique: de l'évaluation des terres à la recherche en géomorphologie. Géomorphol. Relief Process. Environ. 15, 187-198. http://dx.doi.org/10.4000/geomorphologie.7626.

Brevik, E.C., 1999. George Nelson Coffey: early American pedologist. Soil Sci. Soc. Am. J. 63 (6), 1485-1493. http://dx.doi.org/10.2136/sssaj1999.6361485x.

Brevik, E.C., Miller, B.A., 2015. The use of soil surveys to aid in geologic mapping with an emphasis on the eastern and Midwestern United States. Soil Horiz. 56 (4). http://dx. doi.org/10.2136/sh15-01-0001.

Brevik, E.C., Fenton, T.E., Homburg, J.A., 2016a. Historical highlights in American soil science - prehistory to the 1970s. In: Catena, Dan H. Yaalon Memorial Issue. 146. pp. 111-127. http://dx.doi.org/10.1016/j.catena.2015.10.003.

Brevik, E.C., Fenton, T.E., Homburg, J.A., 2016b. Historical highlights in American soil science - prehistory to the 1970s. Catena 146, 111-127. http://dx.doi.org/10.1016/ j.catena.2015.10.003.

Brevik, E.C., Calzolari, C., Miller, B.A., Pereira, P., Kabala, C., Baumgarten, A., Jordán, A., 2016c. Soil mapping, classification, and modeling: history and future directions. Geoderma 264, 256-274. http://dx.doi.org/10.1016/j.geoderma.2015.05.017.

Brevik, E.C., Homburg, J.A., Sandor, J.A., 2017. Soils, climate, and ancient civilizations. In: Changing Soil Processes and Ecosystem Properties in the Anthropocene. Elsevier, Amsterdam.

Bridges, E.M., 1981. Soil geography: a subject transformed. Prog. Phys. Geogr. 5, 398-407. http://dx.doi.org/10.1177/030913338100500303.

Bui, L.V., Stahr, K., Clemens, G., 2017. A fuzzy logic slope-form system for predictive soil mapping of a landscape-scale area with strong relief conditions. Catena 155, 135-146. http://dx.doi.org/10.1016/j.catena.2017.03.001.

Buol, S.W., Southard, R.J., Graham, R.C., McDaniel, P.A., 2011. Soil Genesis and Classification. Wiley-Blackwell, Oxford, UK. http://dx.doi.org/10.1002/ 9780470960622 .

Butzer, K.W., 2005. Environmental history in the Mediterranean world: cross-disciplinary investigation of cause-and-effect for degradation and soil erosion. J. Archaeol. Sci. 32, 1773-1800. http://dx.doi.org/10.1016/j.jas.2005.06.001.

Cerdà, A., Rodrigo-Comino, J., Giménez-Morera, A., Keesstra, S.D., 2017. An economic, perception and biophysical approach to the use of oat straw as mulch in Mediterranean rainfed agriculture land. Ecol. Eng. 108, 162-171. http://dx.doi.org/ 10.1016/j.ecoleng.2017.08.028.

Chen, L., Wei, W., Fu, B., Lü, Y., 2007. Soil and water conservation on the loess plateau in 
China: review and perspective. Prog. Phys. Geogr. 31, 389-403. http://dx.doi.org/ $10.1177 / 0309133307081290$.

Claval, P., 2001. Épistémologie de la géographie. Nathan (Coll. «fac»), Paris, France.

Conacher, A.J., Dalrymple, J.B., 1977. The nine unit landsurface model and pedogeomorphic research. Geoderma 18, 1-154. http://dx.doi.org/10.1016/0016-7061(77) 90087-8.

Dent, D., Young, A., 1981. Soil Survey and Land Evaluation. George Allen \& Unwin, London, UK.

Desruelles, S., Fouache, E., Eddargach, W., Cammas, C., Wattez, J., Beuzen-Waller, T., Martin, C., Tengberg, M., Cable, C., Thornton, C., Murray, A., 2016. Evidence for early irrigation at Bat (Wadi Sharsah, northwestern Oman) before the advent of farming villages. Quat. Sci. Rev. 150, 42-54. http://dx.doi.org/10.1016/j.quascirev. 2016.08 .007$.

Dobrovol'skii, G.V., 2006. Soil science as an interdisciplinary synthetic science. Eurasian Soil Sci. 39, S2-S5. http://dx.doi.org/10.1134/S1064229306130023.

Dobrovol'skii, G.V., 2011. The great predecessor of V.V. Dokuchaev and V.I. Vernadsky. Eurasian Soil Sci. 44, 1173. http://dx.doi.org/10.1134/S1064229311110020.

Duchaufour, P., 1956. Pédologie, Applications forestiéres et agricoles. École nationale des Eaux et Forets, Nancy.

Duchaufour, P., 1970. Précis de pédologie, 3th ed. Masson et Cie, Paris, France.

Duchaufour, P., 1997. Abrege de pedologie. Sol, végétation, environnement, 5th ed. Elsevier Masson, Paris, France.

Duchaufour, P., 1998. Réflexions sur les classifications des sols. In: Presented at the 16th Global workshop of IUSS, Montpellier, pp. 201205.

Eitel, B., Faust, D., 2013. Bodengeographie, Das Geographische Semin. Westermann, Braunschweig, Germany.

Eltner, A., Mulsow, C., Maas, H.-G., 2013. Quantitative measurement of soil erosion from Tls and Uav data. Int. Arch. Photogramm. Remote. Sens. Spat. Inf. Sci. 1, 119-124. http://dx.doi.org/10.5194/isprsarchives-XL-1-W2-119-2013.

Ferreras, C., Fidalgo, C., 1991. Biogeografía y Edafogeografía. Editorial Síntesis, S. A., Madrid, Spain.

Fitzpatrick, E.A., 1980. Soils: Their Formation, Classification and Distribution. Longman, London, UK.

Florinsky, I., Eilers, R.G., Manning, G., Fuller, L., 2002. Prediction of soil properties by digital terrain modeling. Environ. Model. Softw. 17, 295-311. http://dx.doi.org/10 1016/S1364-8152(01)00067-6.

Galati, A., Crescimanno, M., Gristina, L., Keesstra, S., Novara, A., 2016. Actual provision as an alternative criterion to improve the efficiency of payments for ecosystem services for C sequestration in semiarid vineyards. Agric. Syst. 144, 58-64. http://dx. doi.org/10.1016/j.agsy.2016.02.004.

Gaucher, G., 1968. Traité de pédologie agricole. Le sol et ses caractéristiques agronomiques. Dunod, Paris.

Gaucher, G., 1981. Traite de pédologie agricole. Tome II. Les facteurs de la pedogenèse. Lelotte, Dison.

Gebhardt, H., Glaser, R., Radtke, U., Reuber, P., 2012. Geographie - Physische Geographie und Humangeographie. Springer Spektrum, Heidelberg.

Gessler, P.E., Chadwick, O.A., Chamran, F., Althouse, L., Holmes, K., 2000. Modeling soil-landscape and ecosystem properties using terrain attributes. Soil Sci. Soc. Am. J. 64, 2046-2056. http://dx.doi.org/10.2136/sssaj2000.6462046x.

Glinka, K.D., 1914. Die Typen der Bodenbildung, irhe Klassification und Geographische Verbreitung. Gebruder Borntraeger, Berlin, Germany.

Glinka, K.D., Marbut, C.F., 1927. The great soil groups of the world and their development. In: Ann Arbor, Mich., Mimeographed and printed by Edwards brothers, USA

Gong, Z., Zhang, X., Chen, J., Zhang, G., 2003. Origin and development of soil science in ancient China. Geoderma 115, 3-13.

Grunewald, S., 2009. Multi-criteria characterization of recent digital soil mapping and modeling approaches. Geoderma 152, 195-207. http://dx.doi.org/10.1016/j geoderma.2009.06.003.

Harrower, M.J., 2010. Geographic information systems (GIS) hydrological modeling in archaeology: an example from the origins of irrigation in southwest Arabia (Yemen) J. Archaeol. Sci. 37, 1447-1452. http://dx.doi.org/10.1016/j.jas.2010.01.004.

Hartemink, A.E., 2009. The depiction of soil profiles since the late 1700s. Catena 79, 113-127. http://dx.doi.org/10.1016/j.catena.2009.06.002.

Helms, D., 2002. Early leaders of the soil survey. In: Profiles in the History of the U.S. Soil Survey. Ames: Iowa State Press, Iowa, USA, pp. 19-64.

Helms, D., 2005. Kellogg, Charles Edwin, in: American National Biography: Supplement 2. Oxford University Press, Oxford, UK, Oxford, pp. 307-308.

Hilgard, E.W., 1860. Soils, their Formation, Properties, Composition, and Relations to Climate and Plant Growth in the Humid and Arid Regions. Macmillan, New York, USA.

Hilgard, E.W., 1882. Report on the relations of soil to climate. U. S. Dep. Agric. Weather Bull. 3, 1-59.

Hilgard, E.W., 1907. Soils, Their Formation, Properties, Composition, and Relations to Climate and Plant Growth in the Humid and Arid Regions. Macmillan, New York. http://dx.doi.org/10.5962/bhl.title.24461.

Holliday, V.T., 2006. A History of Soil Geomorphology in the United State. In: Footprints in the Soil: People and Ideas in Soil History. Elsevier, Amsterdam, pp. 187-254.

Hope, A.L.B., Jones, C.R., 2014. The impact of religious faith on attitudes to environmental issues and carbon capture and storage (CCS) technologies: a mixed methods study. Technol. Soc. 38, 48-59. http://dx.doi.org/10.1016/j.techsoc.2014.02.003.

Howard, J.L., Olszewska, D., 2011. Pedogenesis, geochemical forms of heavy metals, and artifact weathering in an urban soil chronosequence, Detroit, Michigan. Environ. Pollut. 159 (3), 754-761. http://dx.doi.org/10.1016/j.envpol.2010.11.028.

Howard, J.L., Shuster, W.D., 2015. Experimental Order 1 soil survey of vacant urban land, Detroit, Michigan, USA. Catena 126, 220-230. http://dx.doi.org/10.1016/j.catena. 2014.11.019.
Huguet del Villar, E., 1929. Geoedafología. Método universal de tipología de suelos como base de su cartografía harmónica. Geocrítica, Barcelona, Spain.

Ibáñez, J.J., Zinck, J.A., Dazzi, C., 2013. Soil geography and diversity of the European biogeographical regions. Geoderma 192, 142-153. http://dx.doi.org/10.1016/j. geoderma.2012.07.024.

Ibáñez, J.J., Pérez-Gómez, R., Brevik, E.C., Cerdà, A., 2016. Islands of biogeodiversity in arid lands on a polygons map study: detecting scale invariance patterns from natural resources maps. Sci. Total Environ. 573, 1638-1647. http://dx.doi.org/10.1016/j. scitotenv.2016.09.172.

Isachenko, A.G., 2003. Introduction to Ecological Geography. SGU, St. Petersburg, Russia.

IUSS Working Group WRB, 2006. Guidelines for constructing smallscale map legends using the WRB. In: World Soil Resources, 2nd ed. FAO, Rome.

IUSS Working Group WRB, 2014. World Reference Base for Soil Resources 2014, World Soil Resources Report. FAO, Rome.

Jacquier, D., Schoknecht, Fitzpatrick, R., Powell, McKenzie, N., Maschmedt, D., 2002. In: Rice, T., Eswaran, H., Stewart, B., Ahrens, R. (Eds.), Demands on soil classification in Australia. CRC Press, Soil Classification, pp. 77-100. http://dx.doi.org/10.1201/ 9781420040364.ch9.

Jenny, H., 1961. Derivation of state factor equations of soils and ecosystems. Soil Sci. Soc. Am. J. 25, 385-388. http://dx.doi.org/10.2136/sssaj1961. 03615995002500050023x.

Jie, C., Jing-zhang, C., Man-zhi, T., Zi-tong, G., 2002. Soil degradation: a global problem endangering sustainable development. J. Geogr. Sci. 12, 243-252. http://dx.doi.org/ 10.1007/BF02837480.

Keesstra, S.D., Quinton, J.N., van der Putten, W.H., Bardgett, R.D., Fresco, L.O., 2016. The significance of soils and soil science towards realization of the United Nations sustainable development goals. Soil 2 (2), 128. http://dx.doi.org/10.5194/soil-2-1112016.

Keesstra, S., Nunes, J., Novara, A., Finger, D., Avelar, D., Kalantari, Z., Cerdà, A., 2018 The superior effect of nature based solutions in land management for enhancing ecosystem services. Sci. Total Environ. 610, 997-1009.

Kellogg, C.E., 1937. Soil Survey Manual. U.S. Department of Agriculture Miscellaneous Publication, Washington, D.C., USA.

Kiryushin, V.I., 2006. V. V. Dokuchaev and the present-day paradigm of nature management. Eurasian Soil Sci. 39, 1157-1163. http://dx.doi.org/10.1134/ S1064229306110019.

Krupenikov, I.A., 1992. History of Soil Science from its Inception to the Present. Oxonian Press, New Delhi.

Kubiëna, W.L., 1952. Claves sistemáticas de suelos: diagnóstico y sistemática ilustrados de los suelos más importantes de Europa con sus sinónimos más usuales. Consejo Superior de Investigaciones Científicas, Madrid.

Kubiëna, W.L., 1953. The Soils of Europe. Thomas Murby and company, London, UK.

Lankford, N., Gentzler, L., Garwood, D., Norris, T., Roberts, R., Stewart, C., 1985a. Unpublished materials of Dr. Curtis fletcher Marbut. Soil Horiz. 26, 36-40. http://dx. doi.org/10.2136/sh1985.1.0036.

Lankford, N., Tandarich, J.P., Johannsen, C.J., Morrow, L., 1985b. A photo story of Dr. Curtis fletcher Marbut. Soil Horiz. 26, 19-24. http://dx.doi.org/10.2136/sh1985.1. 0019.

Le Bissonnais, Y., Montier, C., Jamagne, M., Daroussin, J., King, D., 2002. Mapping erosion risk for cultivated soil in France. Catena 46, 207-220. http://dx.doi.org/10. 1016/S0341-8162(01)00167-9.

Lomonosov, M.V., Rowland, S.M., Korolev, S., 2012. On the strata of the Earth a translation of O Слояхъ Земныхъ. Geol. Soc. Am. Spec. Pap. 485, 1-41. http://dx.doi.org/ $10.1130 / 2012.2485$.

Marbut, C.F., 1935. Soils of the United States. USDA Atlas of American Agriculture (Part 3). US Government Printing Office, Washington, DC.

McCracken, R., Helms, D., 1994. Soil surveys and maps. In: McDonald, P. (Ed.), The Literature of Soil Science. Cornell Univ. Press, Ithaca, New York (USA).

Melnyk, A., 2008. Ecological analysis of landscapes. In: Methodology of Landscape Research. Commission of Cultural Landscape of Polish Geograph Ical Society, Sosnowiec, Poland, pp. 151-169.

Miller, B.A., Schaetzl, R.J., 2014. The historical role of base maps in soil geography. Geoderma 230-231, 329-339. http://dx.doi.org/10.1016/j.geoderma.2014.04.020.

Minasny, B., McBratney, A.B., 2016. Digital soil mapping: a brief history and some lessons. Geoderma 264, 301-311. http://dx.doi.org/10.1016/j.geoderma.2015.07.017.

Moon, D., 2005. The environmental history of the Russian Steppes: Vasilii Dokuchaev and the harvest failure of 1891. Trans. R. Hist. Soc. 15, 149-174.

Muggler, C.C., Spaargaren, O., Hartemink, A.E., 2012. The Glinka memorial soil monolith collection: a treasure of soil science. In: Presented at the EGU General Assembly Conference Abstracts, pp. 14239.

Mulder, V.L., de Bruin, S., Schaepman, M.E., Mayr, T.R., 2011. The use of remote sensing in soil and terrain mapping - a review. Geoderma 162, 1-19. http://dx.doi.org/10. 1016/j.geoderma.2010.12.018.

Narany, T.S., Aris, A.Z., Sefie, A., Keesstra, S., 2017. Detecting and predicting the impact of land use changes on groundwater quality, a case study in Northern Kelantan, Malaysia. Sci. Total Environ. 599, 844-853. http://dx.doi.org/10.1016/j.scitotenv. 2017.04.171.

Northcote, K.H., Northcote, K.H., 1979. A Factual Key for the Recognition of Australian Soils, 4th ed. Adelaide: Rellim Technical Publications, Adelaide, Australia.

Oldfield, J.D., Shaw, D.J.B., 2013. V.I. Vernadskii and the development of biogeochemical understandings of the biosphere. Br. J. Hist. Sci. 46, 287-310. http://dx.doi.org/10. 1017/S0007087412000015.

Olson, L., 1943. Columella and the beginning of soil science. Agric. Hist. 17 (2), 65-72.

Ortega Valcárcel, J., 2000. Los horizontes de la geografía: teoría de la geografía. Ariel, Barcelona, Spain.

Ospitali, F., Smith, D.C., orblanchet, M., 2006. Preliminary investigations by Raman 
microscopy of prehistoric pigments in the wall painted cave at Roucadour, Quercy, France. J. Raman Spectrosc. 37 (10), 1063-1071. http://dx.doi.org/10.1002/jrs. 1611.

Parras-Alcántara, L., Lozano-García, B., Keesstra, S., Cerdà, A., Brevik, E.C., 2016. Longterm effects of soil management on ecosystem services and soil loss estimation in olive grove top soils. Sci. Total Environ. 571 498-50. https://doi.org/10.1016/j. scitotenv.2016.07.016

Pears, N., 1985. Basic Biogeography. Longman Publishing Group, London, UK.

Pereira, P., Giménez-Morera, A., Novara, A., Keesstra, S., Jordán, A., Masto, R.E., Cerdà, A., 2015. The impact of road and railway embankments on runoff and soil erosion in eastern Spain. Hydrol. Earth Syst. Sci. Discuss. 12, 12947-12985. http://dx.doi.org/ 10.5194/hessd-12-12947-2015.

Pereira, P., Brevik, E., Cerdà, A., Úbeda, X., Novara, A., Francos, M., Rodrigo Comino, J., Bogunovic, I., Khaledian, Y., 2017. Mapping ash CaCO3, pH and extractable elements using principal component analysis.

Philipponneau, P., 1999. La Géographie appliquée. Du géographe universitaire au géographe professionnel. Armand Colin, Paris, France.

Pickett, S.T.A., Cadenasso, M.L., Grove, J.M., Groffman, P.M., Band, L.E., Boone, C.G., Burch, W.R., Grimmond, C.S.B., Hom, J., Jenkins, J.C., Law, N.L., Nilon, C.H., Pouyat, R.V., Szlavecz, K., Warren, P.S., Wilson, M.A., 2008. Beyond urban legends: an emerging framework of urban ecology, as illustrated by the Baltimore ecosystem study. Bioscience 58 (2), 139-150. http://dx.doi.org/10.1641/B580208.

Porta, J., López-Acevedo, M., Poch, R., 2014. Edafología: uso y protección de suelos, Tercera. ed. Mundiprensa, Madrid.

Prokhorov, A.M., 1982. Great Soviet Encyclopedia. MacMillan Publishing Company.

Ramman, F., 1893. Forstliche Bodenkunde und Standortslehre. Verlag von Julius Springer, Berlin, Germany.

Riquier, J., Bramao, D.L., Cornet, J.-P., 1970. A New System of Soil Appraisal in Terms of Actual and Potential Productivity (First Approximation). FAO, Rome, Italy.

Rodrigo-Comino, J., 2017. Un análisis geomorfológico y edafogeográfico del territorio. Editorial Académica Española, OmniScriptum Management GmbH, Saarbrüicken, Germany.

Rodrigo-Comino, J., Senciales González, J.M., 2013. La Edafogeografía: la quinta rama olvidada de la Geografía Física. Cuad. Geográfic. 52, 6-28.

Rodrigo-Comino, J., Ferre Bueno, E., Senciales, J.M., 2016. Los suelos de Casapalma (Valle del Guadalhorce, Málaga). Análisis edafogeográfico aplicado a la ordenación del territorio. Estud. Geográfic. 77, 275-310. http://dx.doi.org/10.3989/estgeogr. 201610.

Rodrigo-Comino, J., Davis, J., Keesstra, S., Cerdà, A., 2017a. Updated measurements in vineyards improve accuracy of soil erosion rates. Agron. J. http://dx.doi.org/10. 2134/agronj2017.07.0414. (in press).

Rodrigo-Comino, J.R., Bogunovic, I., Mohajerani, H., Pereira, P., Cerdà, A., Ruiz Sinoga, J.D., Ries, J.B., 2017b. The impact of vineyard abandonment on soil properties and hydrological processes. Vadose Zone J. 0 (0). http://dx.doi.org/10.2136/vzj2017.05. 0096.

Rukhovich, D.I., Wagner, V.B., Vil'chevskaya, E.V., Kalinina, N.V., Koroleva, P.V., 2011. Problems of using digitized thematic maps on the territory of the former soviet union upon the creation of the "soils of Russia" geographic information system. Eurasian Soil Sci. 44, 957. http://dx.doi.org/10.1134/S1064229311090110.

Sack, D., 2002. The educational value of the history of geomorphology. In: Geomorphology, Geomorphology in the Public Eye: Political Issues, Education, and the Public. 47. pp. 313-323. http://dx.doi.org/10.1016/S0169-555X(02)00091-0.

Sánchez-Puig, M., 1995. Diccionario de autores rusos. Ediciones de oro, Madrid, Spain.

Schaefer, F.K., 1953. Exceptionalism in geography: a methodological examination. Ann. Assoc. Am. Geogr. 43, 226-249. http://dx doi.org/10.2307/2560876.

Semyonov, P.P., 1998. Travels in the Tian'-Shan' 1856-1857. Edited by Colin Thomas, London, UK.

Sharma, N.K., Singh, R.J., Mandal, D., Kumar, A., Alam, N.M., Keesstra, S., 2017. Increasing farmer's income and reducing soil erosion using intercropping in rainfed maize-wheat rotation of Himalaya, India. Agric. Ecosyst. Environ. 247, 43-53. http:// dx.doi.org/10.1016/j.agee.2017.06.026.

Shaw, D.J.B., Oldfield, J.D., 2007. Landscape science: a Russian geographical tradition. Ann. Assoc. Am. Geogr. 97, 111-126. http://dx.doi.org/10.1111/j.1467-8306.2007. 00526.x.

Shaw, D.J.B., Oldfield, J.D., 2015. Soviet geographers and the great patriotic war, 1941-1945: lev berg and Andrei Grigor'ev. J. Hist. Geogr. 47, 40-49. http://dx.doi. org/10.1016/j.jhg.2014.06.002.

Simonson, R.W., 1986. Historical aspects of soil survey and soil classification. In: Soil Science Society of America, Madison, USA. ACSESS Publications, pp. 3-9. http://dx. doi.org/10.2136/1987.historicalaspectssoil.c3.
Strahler, A.N., Strahler, A., 2002. Introducing Physical Geography, 3th ed. John Wiley \& Sons Inc.

Stremme, H., 1928. General Map of the Soils of Europe (Ogolna Mapa Gleb Europy). International Society of Soil Science, Warszawa.

Stremme, H., 1937. International Soil Map of Europe, 1:2 500 000. Gea Verlag, Berlin.

Stremme, H.E., 1997. Preparation of the collaborative soil maps of Europe, 1927 and 1937. In: Yaalon, D.H., Berkowicz, S. (Eds.), History of Soil Science: International Perspectives. Advances in Geoecology. Catena Verlag, Armelgasse 11/35447 Reiskirchen/Germany, pp. 145-158.

Striganova, B.P., 2013. The contribution of M.S. Giliarov to the theory of evolution. Zh. Obshch. Biol. 74, 409-419.

Tabor, J.A., O'rourke, M.K., Lebowitz, M.D., Harris, R.B., 2011. Landscape-epidemiological study design to investigate an environmentally based disease. J. Expo. Sci. Environ. Epidemiol. 21, 197-211. http://dx.doi.org/10.1038/jes.2009.67.

Tandarich, J.P., Darmody, R.G., Follmer, L.R., Johnson, D.L., 2002. Historical development of soil and weathering profile concepts from Europe to the United States of America. Soil Sci. Soc. Am. J. 66, 335-346. http://dx.doi.org/10.2136/sssaj2002. 3350.

Taylor, J.A., 1984. Themes in Biogeography. Croom Helm, London.

Taylor, J.A., Coulouma, G., Lagacherie, P., Tisseyre, B., 2009. Mapping soil units within a vineyard using statistics associated with high-resolution apparent soil electrical conductivity data and factorial discriminant analysis. Geoderma 153, 278-284. http://dx.doi.org/10.1016/j.geoderma.2009.08.014.

Tricart, J., 1962. L'Epiderme de la Terre. Esquisse d'une géomorphologie appliquée. Masson, Paris.

Tricart, J., Kilian, J., 1982. La Eco-geografia y la ordcnación del medio natural. Anagrama, Barcelona, Spain.

Trudgill, S.T., 1983. Soil geography: spatial techniques and geomorphic relationships. Prog. Phys. Geogr. 7 (3), 345-360. http://dx.doi.org/10.1177/ 030913338300700303.

Trujillo-González, J.M., Mahecha-Pulido, J.D., Torres-Mora, M.A., Brevik, E.C., Keesstra, S.D., Jiménez-Ballesta, R., 2017. Impact of potentially contaminated river water on agricultural irrigated soils in an equatorial climate. Agriculture 7 (7), 52. http://dx doi.org/10.3390/agriculture7070052.

Tugel, A.J., Herrick, J.E., Brown, J.R., Mausbach, M.J., Puckett, W., Hipple, K., 2006. Soil change, soil survey, and natural resources decision making. Soil Sci. Soc. Am. J. 70, 1416. http://dx.doi.org/10.2136/sssaj2004.0163er.

Vaezi, A.R., Abbasi, M., Keesstra, S., Cerdà, A., 2017. Assessment of soil particle erodibility and sediment trapping using check dams in small semi-arid catchments. Catena 157, 227-240. http://dx.doi.org/10.1016/j.catena.2017.05.021.

Verstappen, H.T., van Zuidam, R.A., Meijerink, A.M., 1991. The ITC System of Geomorphologic Survey: A Basis for the Evaluation of Natural Resources and Hazards. International Institute for Aerial Survey and Earth Sciences (ITC), Enschede.

Villacís, J., Casanoves, F., Hang, S., Keesstra, S., Armas, C., 2016. Selection of forest species for the rehabilitation of disturbed soils in oil fields in the Ecuadorian Amazon. Sci. Total Environ. 566, 761-770. http://dx.doi.org/10.1016/j.scitotenv.2016.05. 102.

Wilde, S.A., 1949. Glinka's later ideas on soil classification. Soil Sci. 67, 411-414.

Williams, M., 1994. The relations of environmental history and historical geography. J. Hist. Geogr. 20, 3-21. http://dx.doi.org/10.1006/jhge.1994.1002.

Yaalon, D.H., Berkowicz, 1997. History of Soil Science - International Perspectives. In: Catena Verlag. Reiskirchen, Germany.

Yin, X., Song, B., Dong, W., Xin, W., Wang, Y., 2010. A review on the eco-geography of soil fauna in China. J. Geogr. Sci. 20, 333-346. http://dx.doi.org/10.1007/s11442010-0333-4.

Young, A., Goldsmith, P.F., 1977. Soil survey and land evaluation in developing countries a case study in Malawii. Geogr. J. 143, 407-431. http://dx.doi.org/10.2307/634710.

Yousefi, S., Keesstra, S., Pourghasemi, H.R., Surian, N., Mirzaee, S., 2017. Interplay between river dynamics and international borders: the Hirmand River between Iran and Afghanistan. Sci. Total Environ. 586, 492-501.

Zinck, J.A., 2012. Geopedología. Elementos de geomorfología para estudios de suelos y de riesgos naturales. ITC, Enschede. In: The Netherlands.

Zinck, J.A., Valenzuela, C.R., 1990a. Soil geographic database: structure and application examples. ITC J. 1990, 270-294.

Zinck, J.A., Valenzuela, C.R., 1990b. Soil geographic database: structure and application examples. ITC J. 1990, 270-294.

van Zuidam, R.A., van Zuidam-Cancelado, F.I., 1979. Terrain Analysis and Classification Using Aerial Photographs: A Geomorphological Approach. In: International Institute for Aerial Survey and Earth Sciences. ITC, Enschede, the Netherlands. 